\title{
Study of High Sensitive C-Reactive Protein in Ischemic Heart Disease
}

\author{
BA Ferduos ${ }^{1}$, N Sultana ${ }^{2}$, S Ahmed ${ }^{3}$, EH Khan ${ }^{4}$, F Atia ${ }^{5}$, S Sultana ${ }^{1}$, A Shahnaj ${ }^{2}$ \\ ${ }^{1}$ Department of Biochemistry, Marks Medical College, Dhaka \\ ${ }^{2}$ Department of Biochemistry, Dhaka Medical College, Dhaka \\ ${ }^{3}$ Department of Biochemistry, Popular Medical College, Dhaka \\ ${ }^{4}$ Department of ENT, Holly Family Red Crescent Medical College Hospital \\ ${ }^{5}$ Adhanik Sadar Hospital, Nilphamari
}

\begin{abstract}
C-reactive protein (CRP) is a sensitive marker of inflammation, and elevated levels have been associated with future risk of myocardial infarction (MI). Even elevated CRP in healthy men and women can predict the future coronary events. This cross-sectional analytical study was undertaken to observe association between high hsCRP level with chronic ischaemic heart disease and was conducted in the Department of Biochemistry, Dhaka Medical College, Dhaka from July 2010 to June 2011. A total 50 cases were selected purposively according to the selection criteria form the patients admitted in the Department of Cardiology, Dhaka Medical College Hospital with chronic ischaemic heart disease (IHD). Diagnosed IHD patients were taken as cases; age- and sex-matched 50 healthy subjects were taken as controls. Serum hsCRP and serum TC, TAG, LDL-C and HDL-C were measured in all study subjects. The mean serum hsCRP concentration in cases and controls were 11.22 \pm 7.64 $\mathrm{mg} / \mathrm{dl}$ and $1.72 \pm 0.98 \mathrm{mg} / \mathrm{dl}$ respectively. Serum hsCRP, Total Cholesterol, TAG and LDL-C were significantly higher in cases than control subjects. Serum HDL-C was significantly lower in cases than control subjects. The present study reveals that the patients of chronic ischemic heart disease have been found to have close association of increased level of hsCRP.
\end{abstract}

Keywords: Myocardial infarction, c-reactive protein, cholesterol.

\section{Introduction}

Coronary heart disease remains the leading cause of morbidity and mortality in the industrialized world. Clinical and laboratory studies have shown that inflammation plays a major role in the initiation, progression and destabilization of atheroma. ${ }^{1} \mathrm{C}$ - reactive protein is a non-specific acute phase protein produced by liver in response to injury, infection and inflammation. CRP was discovered nearly 70 years ago by scientists exploring the human inflammatory response. ${ }^{2}$ In the recent past there has been addition of several molecular markers to the well established risk factors of smoking, family history, hypertension, diabetes and high levels of LDL cholesterol. These include the inflammatory markers C-reactive protein (CRP), serum amyloid A and interleukin-6. Of these inflammatory markers high sensitive CRP measurement has been shown to be the most significant predictor of cardiovascular events. The presence of inflammatory markers such as CRP before a clinical event, is likely to indicate ongoing inflammation associated with vascular events must indicate a greater likely hood of a plaque becoming unstable. ${ }^{3}$ Increased hsCRP is an important prognostic indicator for early risk stratification in patients with an acute coronary syndrome (ACS). Increased hsCRP level, after acute myocardial infarction and during unstable angina correlated to the risk of recurrent attack. ${ }^{4}$ 
BA Ferduos, N Sultana, S Ahmed et al

\section{Materials and Methods}

The study was carried out in the Department of Biochemistry, Dhaka Medical College, Dhaka during the period of July 2010 to June 2011. The patients were taken from the Department of cardiology, Dhaka Medical College Hospital. Chronic IHD patients of both sexs and with age range of 30-65 years were considered as cases; and the controls were age and sex matched healthy volunteers. Cases were the diagnosed (positive ECG findings) chronic IHD patients of both sexes admitted in the hospital during the study period. In this study sample size were taken as 100 . Fifty patients with chronic IHD were taken as cases among which 31 were males and 19 were females; and 50 age- sex and matched healthy volunteers were taken as controls among which 28 were males and 22 were females. All statistical analyses were done by SPSS, version 17.0. Results were expressed as mean \pm SD Student's ' $t$ ' test was done to see the different and $\mathrm{P}<0.05$ was considered as significant

\section{Results}

Sex distribution of the study subjects are presented in Table-I. Group I included 31 males and 19 females of chronic IHD patients of age range 30-65 years. In group II, healthy controls of age range 30-65 years were included where 28 were males and 22 were females.

Table-I: Sex distribution of the study subjects

\begin{tabular}{lcc}
\hline Sex & $\begin{array}{c}\text { Group I } \\
(\mathbf{n}=\mathbf{5 0}) \\
\text { Frequency }\end{array}$ & $\begin{array}{c}\text { Group II } \\
(\mathbf{n}=\mathbf{5 0}) \\
\text { Frequency }\end{array}$ \\
\hline Male & $31(62.0)$ & $28(56.0)$ \\
Female & $19(38.0)$ & $22(44.0)$
\end{tabular}

Figures in parentheses indicate percentage

Table-II shows the level of hsCRP in different groups. In group I (cases) and group II (controls), mean values were $11.22 \pm 7.64 \mathrm{mg} / \mathrm{L}$ with range $3.41-30.8 \mathrm{mg} / \mathrm{L}$ and $1.72 \pm 0.98 \mathrm{mg} /$ $\mathrm{L}$ with range $0.29-3.5 \mathrm{mg} / \mathrm{L}$ respectively.

In group-I (cases), mean values (11.22 \pm 7.64 $\mathrm{mg} / \mathrm{L})$ were significantly higher than group II (healthy controls, $1.72 \pm 0.98 \mathrm{mg} / \mathrm{L}$ ).
Table-II: Level of hsCRP in the study groups

\begin{tabular}{lcccc}
\hline hsCRP $(\mathbf{m g} / \mathbf{L})$ & $\begin{array}{r}\text { Group I } \\
(\mathbf{n}=\mathbf{5 0})\end{array}$ & $\begin{array}{c}\text { Group II } \\
(\mathbf{n}=\mathbf{5 0})\end{array}$ & t value & P value \\
\hline Mean \pm SD & $11.22 \pm 7.64$ & $1.72 \pm 0.9$ & 8.720 & $0.0001^{* * * *}$ \\
Range & 3.4130 .80 & 0.293 .50 & & \\
\hline
\end{tabular}

Unpaired Student's ' $t$ ' test $* * *=$ Significant $(P<0.001)$

\section{Discussion}

Higher concentration of C-reactive protein (excess of $5 \mathrm{mg} / \mathrm{L}$ ) than the serum concentration of 1 to 3 $\mathrm{mg} / \mathrm{L}$ that is associated with cardiovascular risk ${ }^{5}$. The present study has revealed that the mean serum hsCRP concentration $1.72 \pm 0.98 \mathrm{mg} / \mathrm{L}$ with the range $0.29-3.5 \mathrm{mg} / \mathrm{L}$ in healthy control group. This is nearly consistent with several studies. ${ }^{5-7}$ Serum hsCRP concentration found in group I (IHD) ranges from $3.41-30.8 \mathrm{mg} / \mathrm{L}$ with the mean $11.22 \pm 7.64 \mathrm{mg} / \mathrm{L}$. IHD patients of this study has shown serum hsCRP concentration significantly high in comparison to healthy control subjects. Same phenomenon observed in many other studies around the world. ${ }^{8-10}$ Baseline high sensitivity variety of $\mathrm{C}$-reactive protein is a stronger early predictor of cardiovascular events such as fatal and non fatal MI. ${ }^{9}$ In a multivariate analysis found increased hsCRP level was linked to an increased frequency of recurrent angina and ischemic episodes ${ }^{11}$. In patients having an MI, if hsCRP level rises greater than $25 \mathrm{mg} / \mathrm{L}$ then it indicates a higher risk of additional complication of MI such as reinfarction. 12 The higher the peak of hsCRP greater the risk of early complications such as recurrent heart attack and cardiac death. ${ }^{5}$ CRP may be useful in the context of acute chest pain. It has been estimated that $15 \%$ of patients presenting with chest pain who go on to develop myocardial infarction have a negative troponin test. In this scenario an elevated CRP may indicate patients who require more urgent intervention. ${ }^{5}$

In conclusion, the present study reveals that the patients of chronic ischemic heart disease have higher level of hsCRP. Therefore, hsCRP is a promising predictive biomarker of coronary risk. 


\section{References}

1. Rifai N, Ridker PM. High Sensitivity C-Reactive Protein: A novel and promising marker of coronary heart disease. Clinical Chemistry 2001; 47: 403-411.

2. Ridker PM. C-Reactive Protein - A simple test to help predict risk of heart attack and stroke. Circulation 2003; 108: 81.

3. Brown DA, Breit SN. CRP and Vascular Risk. Sydpath; (06/06/2002); Available from: http://www. sydpath.stvincent .com.au/tests /CRPRisk.htm

4. de Winter RJ, Fischer J, Bhola Singh R, Van Straalen JP, Jong TD, Tijssen Jen GP, Sanders GT. C-Reactive protein and cardiac troponin $\mathrm{T}$ in risk stratification: differences in optimal timing of tests early after the onset of chest pain. Clinical Chemistry 2000; 46:1597-1603.

5. Yeh ETH, Willerson JT. Coming of age of CReactive Protein. Circulation 2003; 107: 370-372.

6. Blake \& Ridker 2001; cited by Brown DA, Breit SN. CRP and Vascular Risk. Sydpath; (06/06/2002); Available from: http://www.sydpath.stvincent.com .au/tests/CRPRisk.htm

7. Lab Tests Online; hsCRP, The Test Sample; American Association for Clinical Chemistry, 13/05/2004; Available from: http://www.labtestonline .org/unde rstanding/ analytes/hscrp/glance.htm.
8. Ridker PM, Cushman M, Stampfer MJ, Tracy RP, Hennekens $\mathrm{CH}$. Inflammation, aspirin and the risk of cardiovascular disease in apparently healthy men. N Eng J Med 1997; 336: 973-979.

9. Ridker PM, Glynn RJ, Hennekens CH. C-Reactive protein adds to the predictive value of total and HDL cholesterol in determining risk of first myocardial infarction. Circulation1998; 97: 2007-2011.

10. Koenig W, Sund M, Frohlich M, Fischer HG, Lowel H, Doring A, Hutchison WL, Pepys MB. C-Reactive protein, a sensitive marker of inflammation, predicts future risk of coronary heart disease in initially healthy middle- aged men. Circulation 1999; 99: 237-242.

11. Toss H, Lindahl B, Siegbahn A, Willentin L. Prognostic influence of increased fibrinogen and C-Reactive protein levels in unstable coronary artery disease. Circulation 1997; 96: 4204-4210.

12. Retterstol et al., 2002; cited by Brown DA, Breit SN. CRP and Vascular Risk. Sydpath; (06/06/2002); Available from: http://www.sydpath. stvincent.com. $\mathrm{au} /$ tests/CRPRisk.htm 